\title{
CULTURAL VALUE, BELIEF, BEHAVIOUR AND MYTH IN THAI COUNTRY MUSIC
}

\author{
Robert Alexander Burnett \\ Webster University, Thailand
}

\begin{abstract}
One of the most popular music genres in Thailand is the Thai country music as known as 'Pleng Lukthung'. This paper will examine the place of Pleng Lukthung in modern Thai society and it's transformation from a local, regional cultural form to a national platform that is creating new lines of influence and solidarity which are not bounded by geographically defined spaces.
\end{abstract}

Keywords: Thailand, country music, values, belief, behaviour, myth

\section{INTRODUCTION}

Music is not only an object of entertainment, but it is also a tool used to express and recreate values and belief of communities and subcultures. If we want to study the cultural value, belief, behaviour, and myth of a society, we can study popular music (Guevara, 2005). One of the most popular music genres in Thailand is the Thai country music known as 'Pleng Lukthung'.

This paper will examine the place of Pleng Lukthung in modern Thai society and it's transformation from a local, regional cultural form to a national platform that is creating new lines of influence and solidarity that are not bounded by geographically defined spaces.

Music comes from particular places, and is distributed elsewhere, so a whole range of issues emerge from how and where music is produced in particular contexts, and the means through which music is disseminated and reconstructed in different circumstances by other people removed from the original productive context. Music in part reflects aspects of socio-political experiences of and in places - in lyrics, in sounds, in performing contexts, and in the ways in which music has been produced and is consumed.

Furthermore, many of our everyday understandings about places - be they particular sites such as concert or festival venues; regions with distinct music traditions, or national media institutions - are mediated through and by engagements with popular music. Concurrently, many everyday associations with places come to be defined by musical expressions, on a number of levels. These myths of place are often reinforced in song texts, or the often highly particular spatial discourse of scenes, take for example the urban territoriality of hip hop or panAfrican rhetoric of reggae.

The role of music in today's world is important as a key tool in the process of globalization. People are arguing over the loss of a nation's cultural identity (uniqueness), the influences of Westernization, and the dominance of cultural imperialism. In opposition, there are now no longer geographical boundaries and there is unlimited access to both local and global music. In the case of Thai country music this bringing together of global and local across boundaries could be seen as beneficial.

\section{The Background of Thai Country Music}

Thai country music or Pleng Lukthung is a hybrid genre that integrates Thai and Western music, which has been popular in Thailand since the late 1960's. It derived from Thai folk music that was produced by the local people in different regions such as Li-kay, Mo-lam, Lae, Ram-tad. It borrows from Western popular music styles such as Cha-cha-cha, Rumba, Jazz, Rock and Roll, and Disco. Moreover, Thai country music had been influenced by some Asian music, for example, Indian and Chinese songs (Eamsa-ard, 2006). 
The styles of Thai country music can be both slowsad songs and upbeat-fun songs, sung in Thai with local language, tones, accents, and expressions depending on each region. The content is usually focused on storytelling, folktales, religious stories, traditions, agriculture, social-class, and love in the countryside. Simple musical instruments are used such as 'Kan' which is a local woodwind instrument made of bamboo, and 'Pong-Lang' which is a local percussions instrument made of wood. The characteristics of Thai country music are sincerity, humour, and frankness, some would say the same characteristics as rural people.

According to Damrongloet (1990), Thai country music has been divided into five periods that consist of 1) the beginning period when this musical style was known as 'pleng chao ban' or 'pleng talat' which mean a music for ordinary people during 1938-1964; 2) the golden era when it was named on TV in 1964;

3) the period of movie soundtracks when numerous Thai country music artists became movie actors and actresses during 1970-1973; 4) when Thai country music came to be the style of 'song for life' during 1973-1976, the celebration of democracy and; 5) the period of dance and concerts when the bands of Thai country music performed in concerts with elaborate dance troupes during 1980s-2000s (Eamsa-ard, 2006).

Although Thai country music appeals to both urban and rural populations, it is popular among rural people in the provinces and working class, blue-collar workers who have migrated to the city rather than urban people or white-collar professionals.

\section{Four contexts in Thai Country Music}

\section{Cultural attitudes}

If we see in-depth into the root of the Thai word 'Lukthung' translated as Thai country music, there is a point of interest involving Thai culture. Eamsa-ard (2006) explained that it "means 'a child of the (rice) field' or anyone or anything that is 'born in the countryside, not in towns or cities'." Thus, 'Pleng Lukthung' means the song or music of countryside people.

In addition, Mitchell (2011) stated that Thai country music has a leading role in representing the identity and culture of Isan or the northeastern region of
Thailand such as inferred equality, ethnic solidarity and determined resistance to Bangkok chauvinism.

One can argue that Thai country music represents the various Thai identities from different indigenous ethnic groups of Thai people from four regions of Thailand because Thai country music was influenced by Thai folk music from each of these regions (Eamsa-ard, 2006). However, when talking about Thai country music, Thai people will refer to Isan songs at first because Isan people have moved into mainstream Thai society via participation in the industry as performers and song- writers since the 1960’s (Mitchell, 2011).

Thai country songs of each region are rather different from local language, tones, accents, and expression including local musical instruments. There are four main Thai country music's divided by four cultural regions of Thailand including North country music, Northeast (Isan) country music, Central country music, and South country music.

\section{Values}

Amporn (2006) argues that Thai country music is now portrayed and perceived as an authentic and traditional Thai art form and tradition. Additionally, Thai music country was preserved as Thai heritage and was supported by the Ministry of Culture, and the Office of the National Culture Commission of Thailand, by annually giving The National Artist of Thailand awards to notable Thai artists in many areas including Thai country music.

Furthermore, Thai country music is seen as a significant socializing mechanism that both transmits and reflects norms regarding all social behavior because the lyrical contents of Thai country songs are a manifestation of every dimension of rural society in Thailand including the ways of life, customs and traditions such as the belief in animism and astrology, the values of the main institutions of the nation, religion and monarchy, the values of materialistic behaviour, the values of social class and power, and the different value systems of life in Bangkok and the rural countryside (Damrongloet, 1990).

\section{3) Behaviour}

Thai country music does not only reflect cultural attitudes and values, but it reflects national behaviours and characters such as a sense of humour, loving fun and happiness, playfulness, enjoyment and 
relaxation, forgiveness, a love of convenience and informality, lack of discipline, nepotism, a keen interest in local gossip, social competition, a tendency to forgive social and political dishonesty or unethical behaviour, making decisions by emotion rather than by scientific reasoning, liking to negotiate, and a love of eating (Set-tho, 1989).

Sense of humour and playfulness are obviously seen in Thai country music and concerts because almost all Thai country songs and shows perform in a fun style including the elaborate costumes of singers, dancers, emcees and comedians in Lukthung bands that look like a carnival or musical showcase mixed from a myriad of sources. Some male singers wear suits while female singers wear more varied, sexy, and colourful outfits. Their costumes are expensive, contrasting with the rural life-style, but the costumes appeal to Thai country music's audiences and fans.

\section{Myths}

Although Thai country music is only one of numerous popular music genres in Thailand, it is actually popular among the largest section of the population that are rural people and the urban working classes who have the least power in Thai society. That's why some Thai people, especially Bangkokians, often look down at Thai country music's audiences as country bumpkins (Broughton \& Ellingham, 2000, p.247).

On the other hand, DJ Jenphop Jopkrabuanwan argued that the socio-economic status of the Thai country music audiences has expanded positively, relative to the increase of the Thai middle and urban working class. The audiences do not only come from lower class as almost people think, but they also now come from every class of people (Eamsa-ard, 2006).

\section{CONCLUSION}

In summary, Thai country music has an influential role in Thai society by passing on the way of life and tradition of rural people in its lyrics and rhythms. The word 'Country' doesn't limit the audience to be only from the countryside any more, the group of fans is now spreading to all classes of Thai Society. Nowadays, Thai country music is more advanced by mixing elements from Thai pop music, Rock, R\&B, Hip Hop, and EDM. This modern adaption process of Thai country music seems to appeal to a new younger generation audience and will possibly help to maintain its popularity in modern Thai Society.

\section{REFERENCES}

Amporn Jirattikorn. 2006. 'Lukthung: Authenticity and Modernity in Thai Country Music'. Asian Music 37.1: 2450 .

Broughton, S., \& Ellingham, M. (2000). World music: The Rough guide: An A-Z of the music, musicians and discs. London: The Rough guides.

Damrongloet, J. (1990). Wannakam Pleng Lukthoong [Thai country music literatures]. Bangkok: Sathaban Thai Kadi Sueksa [Thai Studies Institute],Thammasart University.

Eamsa-ard, L. (2006). Thai Popular Music: The Representation of National Identities and Ideologies Within a Culture in Transition. Edith Cowan University.

Guevara, J. C. (2005). Musical Meaning And Communication In PopularMusic. University of Sheffield.

Mitchell, J. (2011). Kon baan diaokan or 'we're from the same village' - star/fan interaction in Thai lukthung. Prbt Perfect Beat, 12(1), 69-80

Set-tho, R. (1989). Krongsang sankom lae watanatham thai [Social structure and Thai culture]. Ba 